\title{
RAM SPERMATOZOA STUDIED WITH TECHNIQUES FOR THE CYTOCHEMICAL DETECTION OF PHOSPHORYLASE AND SUCCINIC DEHYDROGENASE
}

\author{
M. A. Castellano, N. I. Germino, M. MicuGai, A. GOdOY \\ AND V. GRAU \\ Instituto de Anatomia Normal, Repartición Histologia y Embriologia, \\ Facultad de Veterinaria, Montevideo, Uruguay \\ (Received 15th August 1967, revised 20th May 1968)
}

\begin{abstract}
Summary. Frozen ram spermatozoa gave a positive reaction for succinic dehydrogenase and a negative one for phosphorylase. An increase of the succinic dehydrogenase reaction after freezing is interpreted as an augmentation of the cellular permeability.
\end{abstract}

It is well known that ovine spermatozoa do not survive well at low temperatures. In order to study the effects of freezing upon the ovine spermatozoa we performed the reaction for succinic dehydrogenase after different times of freezing. Succinic dehydrogenase was chosen because it is involved in aerobic metabolism. Earlier papers about techniques for the demonstration of oxidative enzymes in intact cells include studies by Edwards \& Valentine (1963), Balogh \& Cohen (1964), Hrudka (1965) and Reissenweber (1966). In addition to succinic dehydrogenase, we also studied the enzyme phosphorylase.

Semen was collected by artificial vagina, and volume, colour, motility, cell density and methylene blue reduction time were estimated. We used only those samples that had normal values, and these were frozen at $-79^{\circ} \mathrm{C}$. Aliquots of the same sample were studied after different periods of refrigeration at $-79^{\circ} \mathrm{C}$, between $1 \mathrm{~min}$ and $48 \mathrm{hr}$. The semen was thawed and $0.05 \mathrm{ml}$ was mixed with $0.45 \mathrm{ml}$ of the incubation medium for the demonstration of succinic dehydrogenase (Nachlas, Tsou, De Souza, Cheng \& Seligman, 1957) using M-nitroneotetrazolium chloride (NB Co); the same dilution was used for the phosphorylase reaction (Takeuchi \& Kuriaki, 1955). The mixture was kept for 20 to $60 \mathrm{~min}$ at $37^{\circ} \mathrm{C}$ for succinic dehydrogenase demonstration and $90 \mathrm{~min}$ at $37^{\circ} \mathrm{C}$ for phosphorylase demonstration. In both cases controls were incubated in similar medium without specific substrates. After incubation smears were made and dried and fixed in $10 \%$ neutral formalin.

With the succinic dehydrogenase method deposits of diformazan were detectable in the mid-pieces of all spermatozoa; the amount of diformazan increased with prolonged incubation. The deposits were granular and evidently located in mitochondria. No diformazan was detected either in the head or tail of spermatozoa. When the thawed semen was incubated for $20 \mathrm{~min}$ the reaction was minimal in samples previously frozen from $1 \mathrm{~min}$ to $2 \mathrm{hr}$; after 
this time the reaction increased and was maximal at $3 \mathrm{hr}$; no subsequent increase was seen in samples frozen for longer times up to $24 \mathrm{hr}$. When the incubation time was $1 \mathrm{hr}$ the reaction was maximal with samples frozen for $15 \mathrm{~min}$; no increase was seen with a longer freezing time. A negative result was obtained with samples after $48 \mathrm{hr}$ of freezing. The reaction for phosphorylase was negative in all samples.

The study by Koefoed-Johnsen \& Mann (1954) has shown that succinate increases the oxygen uptake of immotile spermatozoa, but not of motile spermatozoa. They suggested that succinate does not penetrate the intact living spermatozoa. We are of the opinion that, in the ovine spermatozoa, freezing increases the permeability to succinate. This is in agreement with the results of Koefoed-Johnsen \& Mann (1954) about the stimulating effect of succinate on the rate of respiration of immotile spermatozoa. The presence of diformazan grains in the mid-piece confirms many previous studies which demonstrated the mitochondrial localization of succinic dehydrogenase. We wish to emphasize once more that the enzymatic activity in cells that were frozen for $24 \mathrm{hr}$ occurred in spite of the irreversible loss of movement and fertilizing ability.

We are indebted to Dr G. Gerard for his help throughout the experiments.

\section{REFERENCES}

BALOGH, K., JR \& Cohen, R. B. (1964) A cytochemical technic for studying oxidative enzyme systems of mammalian spermatozoa in semen smears. Fert. Steril. 15, 35.

Edwards, R. G. \& Valentine, R. C. (1963) Cytochemical demonstration of succinic dehydrogenase in intact rabbit spermatozoa. Expl Cell Res. 31, 508.

Hrudka, F. (1965) Cytochemical demonstration of catabolic activity in spermatozoa by the formazan test. F. Reprod. Fert. 10, 15.

Koefoed-Johnsen, H. H. \& Mann, T. (1954) Studies on the metabolism of semen. 9. Effect of surface active agents with special reference to the oxidation of succinate by spermatozoa. Biochem. 7. 57, 406.

Nachlas, M. M., Tsou, K.-C., De Souza, E., Cheng, C.-S. \& Seligman, A. M. (1957) Cytochemical demonstration of succinic dehydrogenase by the use of a new $p$-nitrophenyl substituted ditetrazole. F. Histochem. Cytochem. 5, 420 .

Reissenweber, N.J. (1966) Succinic dehydrogenase activity in rat spermatozoa as demonstrated with various tetrazolium salts. Naturwissenschaften, 53, 133.

TaKeuchi, T. \& Kuriakr, H. (1955) Histochemical detection of phosphorylase in animal tissues. $\mathcal{F}$. Histochem. Cytochem. 3, 153. 